Author(s): Talvitie, Heli \& Vähänissi, Ville \& Haarahiltunen, Antti \& Yli-Koski, Marko \& Savin, Hele

Title:

\title{
Phosphorus and boron diffusion gettering of iron in monocrystalline silicon
}

Year: 2011

Version: Post print

\section{Please cite the original version:}

Talvitie, Heli \& Vähänissi, Ville \& Haarahiltunen, Antti \& Yli-Koski, Marko \& Savin, Hele. 2011. Phosphorus and boron diffusion gettering of iron in monocrystalline silicon. Journal of Applied physics, Volume 109, Issue 9. P. 5. 0021-8979 (printed). DOI: 10.1063/1.3582086.

Note: $\quad$ Copyright 2011 American Institute of Physics. This article may be downloaded for personal use only. Any other use requires prior permission of the author and the American Institute of Physics.

http://scitation.aip.org/content/aip/journal/jap

All material supplied via Aaltodoc is protected by copyright and other intellectual property rights, and duplication or sale of all or part of any of the repository collections is not permitted, except that material may be duplicated by you for your research use or educational purposes in electronic or print form. You must obtain permission for any other use. Electronic or print copies may not be offered, whether for sale or otherwise to anyone who is not an authorised user. 


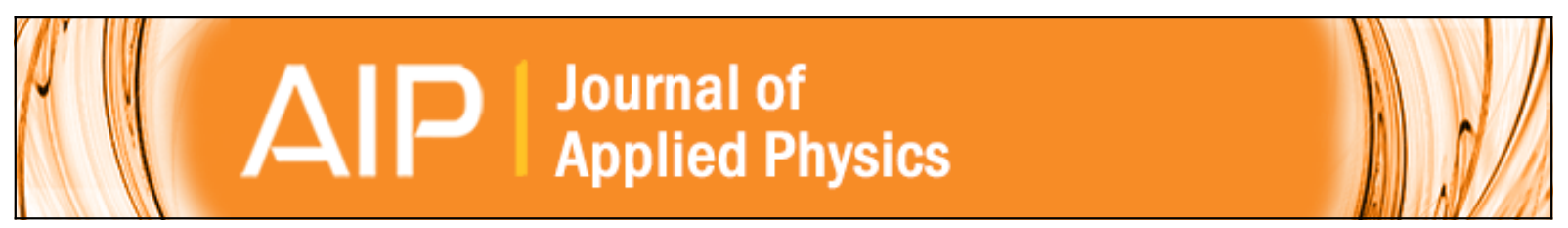

\section{Phosphorus and boron diffusion gettering of iron in monocrystalline silicon}

H. Talvitie, V. Vähänissi, A. Haarahiltunen, M. Yli-Koski, and H. Savin

Citation: Journal of Applied Physics 109, 093505 (2011); doi: 10.1063/1.3582086

View online: http://dx.doi.org/10.1063/1.3582086

View Table of Contents: http://scitation.aip.org/content/aip/journal/jap/109/9?ver=pdfcov

Published by the AIP Publishing

\section{Articles you may be interested in}

Competitive gettering of iron in silicon photovoltaics: Oxide precipitates versus phosphorus diffusion

J. Appl. Phys. 116, 053514 (2014); 10.1063/1.4892015

Direct comparison of boron, phosphorus, and aluminum gettering of iron in crystalline silicon

J. Appl. Phys. 109, 073521 (2011); 10.1063/1.3569890

Modeling phosphorus diffusion gettering of iron in single crystal silicon

J. Appl. Phys. 105, 023510 (2009); 10.1063/1.3068337

Modeling boron diffusion gettering of iron in silicon solar cells

Appl. Phys. Lett. 92, 021902 (2008); 10.1063/1.2833698

Effect of gettered iron on recombination in diffused regions of crystalline silicon wafers

Appl. Phys. Lett. 88, 092105 (2006); 10.1063/1.2181199

You don't

still use this

cell phone

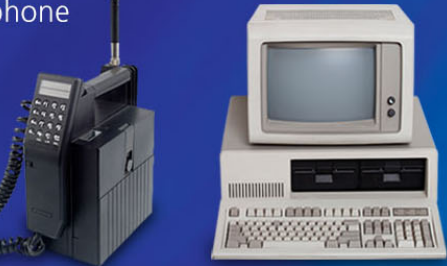

Why are you still using an AFM designed in the 80 's?
It is time to upgrade your AFM

Minimum $\$ 20,000$ trade-in discount for purchases before August 31st

Asylum Research is today's technology leader in AFM 


\title{
Phosphorus and boron diffusion gettering of iron in monocrystalline silicon
}

\author{
H. Talvitie, ${ }^{\text {a) }}$ V. Vähänissi, A. Haarahiltunen, M. Yli-Koski, and H. Savin \\ Department of Micro and Nanosciences, Aalto University, P.O. Box 13500, FI-00076 Aalto, Espoo, Finland
}

(Received 1 December 2010; accepted 10 March 2011; published online 3 May 2011)

\begin{abstract}
We have studied experimentally the phosphorus diffusion gettering (PDG) of iron in monocrystalline silicon at the temperature range of $650-800^{\circ} \mathrm{C}$. Our results fill the lack of data at low temperatures so that we can obtain a reliable segregation coefficient for iron between a phosphorus diffused layer and bulk silicon. The improved segregation coefficient is verified by time dependent PDG simulations. Comparison of the PDG to boron diffusion gettering (BDG) in the same temperature range shows PDG to be only slightly more effective than BDG. In general, we found that BDG requires more carefully designed processing conditions than PDG to reach a high gettering efficiency. (C) 2011 American Institute of Physics. [doi:10.1063/1.3582086]
\end{abstract}

\section{INTRODUCTION}

Phosphorus diffusion gettering (PDG) has been known for a long time as an effective technique to relocate transition metals, such as iron, in silicon wafers. It has been utilized especially in p-type silicon solar cells while diffusing the emitter. Emitter formation by phosphorus diffusion collects iron from the bulk to the phosphorus doped layer, making iron less harmful for the cell operation.

Nadahara et al. ${ }^{1}$ observed already in 1991 that when the phosphorus content of the emitter is kept constant, lower phosphorus diffusion temperature increases the PDG efficiency of iron in monocrystalline silicon. Later, similar results of temperature playing a major role in PDG efficiency have been published. The emphasis has been on improvement of PDG when the diffusion treatment is extended by an anneal step at a lower temperature or slow cooling, both in monocrystalline $^{2-4}$ and multicrystalline silicon. ${ }^{2,5-8}$ The improvement of the performance of a multicrystalline silicon solar cell with a low temperature anneal has been attributed also to iron precipitation to bulk defects. ${ }^{9}$ However, Rinio et $a l .{ }^{10}$ found that the improvement of multicrystalline cells by low temperature annealing is primarily due to PDG and to a lesser extent due to internal gettering to the bulk defects, which was also our conclusion from a theoretical study. ${ }^{11}$

It is well known that iron solubility in silicon increases with phosphorus concentration, which results in iron segregation to a heavily phosphorus doped layer. However, the segregation coefficient of iron between a phosphorus doped layer and bulk silicon and the physical mechanism behind the increased iron solubility have remained unclear, despite the extensive studies. In the absence of proper segregation coefficient, either the segregation coefficient of iron into boron doped silicon $^{12}$ or the properties of cobalt ${ }^{13}$ were used in the past. Recently, a step forward was taken, when a general method to determine the segregation coefficient of iron from the phosphorus diffusion gettering experiments was proposed. ${ }^{14}$ At that time, only limited experimental data was available, ${ }^{1,2}$ which resulted in only a rough estimate of the segregation coefficient.

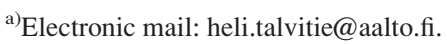

Besides the limited data at low temperatures, the experimental PDG results published previously are not necessarily steady state values, which is critical when determining the segregation coefficient. In this paper, we present a systematic study of phosphorus diffusion gettering in the temperature range of $650-800{ }^{\circ} \mathrm{C}$ with controlled iron contamination level and phosphorus profiles. We confirm by simulations and time dependent experiments that we are measuring the steady state values. We use the obtained results to improve the accuracy of the segregation coefficient of iron in phosphorus diffused silicon. As the increasing interest toward n-type silicon solar cells has drawn attention to the gettering effect of boron diffusion, we also compare the PDG results to boron diffusion gettering (BDG) experiments carried out with similar temperature profiles.

\section{EXPERIMENTAL}

The idea behind the PDG experiments is to have two wafer series with different phosphorous content. This is realized by different phosphorous in-diffusion times (30 $\mathrm{min}$ and $60 \mathrm{~min})$ with constant in-diffusion temperature $\left(870^{\circ} \mathrm{C}\right)$. The in-diffusion is directly followed by various low temperature anneals. Phosphorus in-diffusion at $870^{\circ} \mathrm{C}$ was chosen to avoid (1) too high gettering efficiency (measurement results below the detection limit of $1 \times 10^{10} \mathrm{~cm}^{-3}$ ) and (2) the change of the phosphorus profile during the low temperature anneals.

BDG experiments were designed so that the boron indiffusion resulted in a sheet resistance comparable to the lower phosphorus content samples. The low temperature anneals following the boron in-diffusion were identical to the ones used in the PDG experiments.

Two types of boron doped (100) oriented Czochralskigrown silicon wafers with a diameter of $100 \mathrm{~mm}$ were used as starting material. The first type had a thickness of $525 \mu \mathrm{m}$ and a resistivity of around $17 \Omega \mathrm{cm}$. The other type had a thickness of $400 \mu \mathrm{m}$ and a resistivity of $2.7-3.0 \Omega \mathrm{cm}$. At first the wafers were intentionally contaminated with iron by immersing them in a SC1 solution containing $30 \mathrm{ppb}$ added iron impurities. Iron was diffused into the wafers with a 55 min anneal at $850^{\circ} \mathrm{C}$. The remaining surface iron contamination was removed in a $\mathrm{HF}: \mathrm{H}_{2} \mathrm{O}_{2}: \mathrm{H}_{2} \mathrm{O}$ solution. Wafers were 
cleaned in the sequence of standard wafer cleaning solutions $\mathrm{SC} 1$ and SC2 including dip in diluted HF as the last step. A dry oxide of about $26 \mathrm{~nm}$ thickness was grown on the wafers by a 20 min oxidation at $1000^{\circ} \mathrm{C}$. The oxide was removed from the wafer front sides with BHF before phosphorus or boron diffusion, excluding the wafer which was used to determine the initial iron contamination level. Phosphorus spin-on dopant (Filmtronics P509) was used as phosphorus source and boron spin-on dopant (Filmtronics B154) as boron source in dopant diffusions.

For the low P content wafer series, the $525 \mu \mathrm{m}$ thick wafers were used. One of the wafers received $30 \mathrm{~min}$ phosphorus in-diffusion at $870{ }^{\circ} \mathrm{C}$ followed by ramp down to $800^{\circ} \mathrm{C}$ and unloading there. The other wafers received similar phosphorus in-diffusion but instead of unloading at $800^{\circ} \mathrm{C}$, they received an additional low temperature anneal, i.e., low temperature tail, between 600 and $800^{\circ} \mathrm{C}$. The ramp down rate was $4{ }^{\circ} \mathrm{C} / \mathrm{min}$ from $870^{\circ} \mathrm{C}$ down to $800^{\circ} \mathrm{C}$ and $2{ }^{\circ} \mathrm{C} /$ min below $800^{\circ} \mathrm{C}$. The annealing times at low temperatures were chosen based on simulations ${ }^{14}$ to ensure a steady state iron concentration through the $525 \mu \mathrm{m}$ thick wafers. These wafers are later denoted as " $\mathrm{P}$, high $\mathrm{R}_{\mathrm{s}}$ ".

For the high P content wafer series, the $400 \mu \mathrm{m}$ thick wafers were used. They were subjected to phosphorus in-diffusion at $870^{\circ} \mathrm{C}$ for $60 \mathrm{~min}$ and are later denoted as " $\mathrm{P}$, low $\mathrm{R}_{\mathrm{s}}$ ". BDG experiments were carried out on both wafer types, but in both wafer series boron in-diffusion anneal was chosen to be $60 \mathrm{~min}$ at $930^{\circ} \mathrm{C}$. The wafer series with $525 \mu \mathrm{m}$ thickness is denoted as " $\mathrm{B}$, high $\mathrm{R}_{\mathrm{s}}$ " and the wafer series with $400 \mu \mathrm{m}$ thickness as "B, high $\mathrm{R}_{\mathrm{s}}, 400 \mu \mathrm{m}$ ", respectively. In all these samples, the low temperature anneals and ramp rates were identical with the ones applied to the " $\mathrm{P}$, high $\mathrm{R}_{\mathrm{s}}$ " wafer series described earlier.

All the PDG anneals were carried out in $\mathrm{N}_{2}$ atmosphere and the BDG anneals in a mixture of $\mathrm{N}_{2}$ and $\mathrm{O}_{2}$. After the low temperature anneal, the wafers were air cooled to room temperature. Table I presents a summary of the PDG samples and Table II of the BDG samples, respectively.

Sheet resistances measured with four-point probe measurement are shown in Tables I and II. Iron concentrations in the wafer bulk were measured using surface photovoltage (SPV) method. By SPV, the initial iron contamination level was determined to be $1.7 \times 10^{13} \mathrm{~cm}^{-3}$. In addition, the

TABLE I. PDG anneals applied to the wafers.

\begin{tabular}{|c|c|c|c|c|}
\hline $\begin{array}{l}\text { Wafer } \\
\text { series } \\
\text { notation }\end{array}$ & $\begin{array}{c}\text { Wafer } \\
\text { thickness }\end{array}$ & In-diffusion & $\begin{array}{c}\text { Sheet } \\
\text { resistance }\end{array}$ & $\begin{array}{c}\text { LT anneal } \\
\text { temperature } \\
\text { (anneal time) }\end{array}$ \\
\hline$P$, high $R_{s}$ & $525 \mu \mathrm{m}$ & $\begin{array}{l}30 \mathrm{~min} \\
\text { at } 870^{\circ} \mathrm{C}\end{array}$ & $45 \Omega / \mathrm{sq}$ & $\begin{array}{l}800^{\circ} \mathrm{C}(2 \mathrm{~h}) \\
750^{\circ} \mathrm{C}(3.5 \mathrm{~h}) \\
700^{\circ} \mathrm{C}(5.5 \mathrm{~h}) \\
650^{\circ} \mathrm{C}(8 \mathrm{~h}, 5 \mathrm{~h} \text { and } 1.5 \mathrm{~h}) \\
600^{\circ} \mathrm{C}(15 \mathrm{~h})\end{array}$ \\
\hline $\mathrm{P}$, low $\mathrm{R}_{\mathrm{s}}$ & $400 \mu \mathrm{m}$ & $\begin{array}{l}60 \mathrm{~min} \\
\text { at } 870^{\circ} \mathrm{C}\end{array}$ & $25 \Omega / \mathrm{sq}$ & $\begin{array}{l}800^{\circ} \mathrm{C}(2 \mathrm{~h}) \\
750^{\circ} \mathrm{C}(3.5 \mathrm{~h}) \\
700^{\circ} \mathrm{C}(5.5 \mathrm{~h}) \\
650^{\circ} \mathrm{C}(8 \mathrm{~h})\end{array}$ \\
\hline
\end{tabular}

TABLE II. BDG anneals applied to the wafers.

\begin{tabular}{|c|c|c|c|c|}
\hline $\begin{array}{l}\text { Wafer } \\
\text { series } \\
\text { notation }\end{array}$ & $\begin{array}{c}\text { Wafer } \\
\text { thickness }\end{array}$ & In-diffusion & $\begin{array}{l}\text { Sheet } \\
\text { resistance }\end{array}$ & $\begin{array}{c}\text { LT anneal } \\
\text { temperature } \\
\text { (anneal time) }\end{array}$ \\
\hline $\mathrm{B}$, high $\mathrm{R}_{\mathrm{s}}$ & $525 \mu \mathrm{m}$ & $\begin{array}{l}60 \mathrm{~min} \\
\text { at } 930^{\circ} \mathrm{C}\end{array}$ & $40 \Omega / s q$ & $\begin{array}{l}800^{\circ} \mathrm{C}(2 \mathrm{~h}) \\
750^{\circ} \mathrm{C}(3.5 \mathrm{~h}) \\
700^{\circ} \mathrm{C}(5.5 \mathrm{~h}) \\
650^{\circ} \mathrm{C}(8 \mathrm{~h})\end{array}$ \\
\hline $\mathrm{B}$, high $\mathrm{R}_{\mathrm{s}}, 400 \mu \mathrm{m}$ & $400 \mu \mathrm{m}$ & $\begin{array}{l}60 \mathrm{~min} \\
\text { at } 930^{\circ} \mathrm{C}\end{array}$ & $40 \Omega / s q$ & $\begin{array}{l}800^{\circ} \mathrm{C}(2 \mathrm{~h}) \\
750^{\circ} \mathrm{C}(3.5 \mathrm{~h}) \\
700^{\circ} \mathrm{C}(5.5 \mathrm{~h}) \\
650^{\circ} \mathrm{C}(8 \mathrm{~h}) \\
600^{\circ} \mathrm{C}(15 \mathrm{~h})\end{array}$ \\
\hline
\end{tabular}

phosphorus diffusion profile and iron profile were measured by secondary ion mass spectrometry (SIMS).

\section{RESULTS}

\section{A. Experimental results}

Figure 1 presents iron concentrations in the wafer bulk after the PDG anneals with different low temperature tails. As expected, the bulk iron concentration decreases with the tail temperature. Low temperature anneal at $600^{\circ} \mathrm{C}$ decreases the bulk iron concentration below the detection limit. After each anneal, the iron concentration remains below the iron solubility, which indicates that the gettering is caused by a segregation type equilibrium effect, not by relaxation. It is well known that the longer phosphorus in-diffusion time (higher phosphorus content) and smaller wafer thickness both decrease the bulk iron concentration reached in steady state. Indeed, we see this phenomenon in our samples by comparing the two wafer series. In our case, the difference in wafer thickness should shift the final bulk iron concentration only by a factor of about 1.3. Thus, the difference between the two data series can be largely explained by the difference in phosphorus content.

In contrast to the final gettering efficiency, the temperature dependence does not seem to be affected by the phosphorous content: when we compare the activation energies,

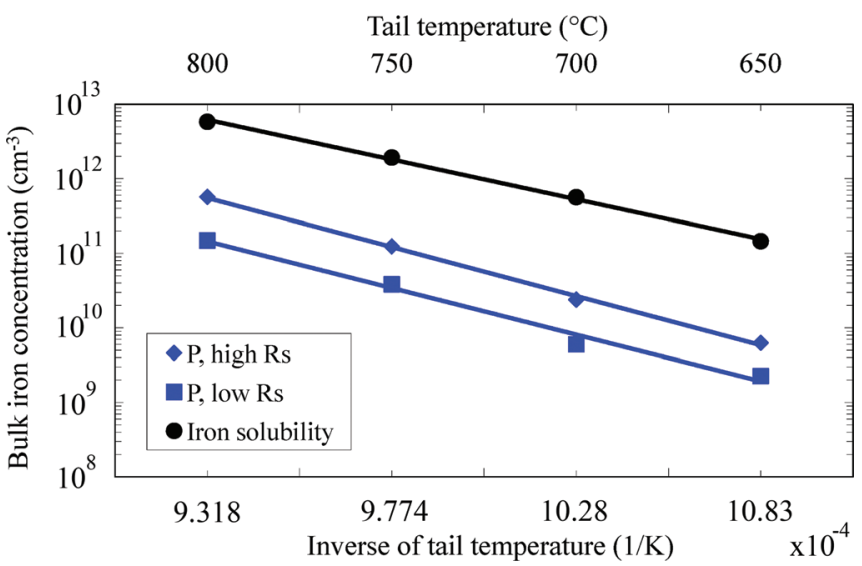

FIG. 1. (Color online) Measured bulk iron concentrations after PDG as a function of the low temperature anneal. Wafer series with $30 \mathrm{~min}$ phosphorus in-diffusion $\left(\mathrm{P}\right.$, high $\mathrm{R}_{\mathrm{s}}$ ) and 60 min phosphorus in-diffusion $\left(\mathrm{P}\right.$, low $\left.\mathrm{R}_{\mathrm{s}}\right)$ are shown, as well as the solid solubility of iron. 
we see almost no difference between the two phosphorus profiles. The activation energies are about $2.6 \mathrm{eV}$ and $2.5 \mathrm{eV}$ in the wafer series diffused for $30 \mathrm{~min}$ and $60 \mathrm{~min}$, respectively. These values are close to the value of $2.4 \mathrm{eV}$, which was determined previously from experiments made at temperatures above $800^{\circ} \mathrm{C} .{ }^{1}$

Next, we compare the PDG to the BDG experiments carried out with identical low temperature anneals. The BDG results have been reported earlier. ${ }^{15}$ The comparison is quite straightforward as the wafers used in the BDG experiments and the PDG experiments presented above were taken from the same ingots and thus the material parameters in BDG and PDG samples are identical. In addition, the sheet resistance in BDG samples matches with the PDG samples diffused for $30 \min \left(\mathrm{P}\right.$, high $\left.\mathrm{R}_{\mathrm{s}}\right)$.

BDG is usually reported to be less effective in iron gettering compared to PDG. ${ }^{4,12}$ However, in our experiments PDG removes iron only slightly more effectively than the corresponding BDG, as shown by the results in Fig. 2. With identically processed but thinner wafers, the gettering efficiency is even better in BDG than in PDG. We have concluded earlier, based on the obtained activation energies that the unexpectedly high BDG efficiency is due to gettering by B-Si precipitates. ${ }^{15}$

As the last experiment, the PDG samples were measured by SIMS. SIMS can provide a depth profile of phosphorus concentration which is needed for the determination of the segregation coefficient. Figure 3 presents the SIMS results of the phosphorus and iron concentrations after $30 \mathrm{~min}$ and 60 min diffusion at $870^{\circ} \mathrm{C}$ followed by $2 \mathrm{~h}$ anneal at $800^{\circ} \mathrm{C}$. The phosphorus concentrations follow the typical kink-andtail profile, $60 \mathrm{~min}$ in-diffusion resulting naturally in a deeper junction than the $30 \mathrm{~min}$ in-diffusion. In both cases, iron has been collected to a shallow surface layer. However, iron gettering efficiency cannot be reliably concluded from the SIMS results. Figure 3 shows also the phosphorus profiles simulated according to the model proposed by Bentzen et al. ${ }^{16}$ The surface concentration was fitted to obtain the best fit of the total phosphorus content. The simulated phos-

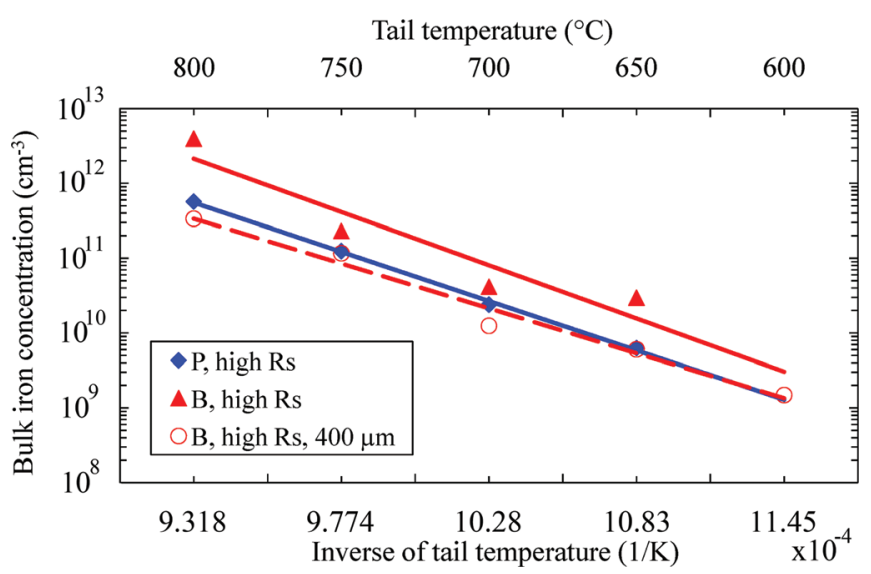

FIG. 2. (Color online) Measured bulk iron concentrations after PDG (P, high $\mathrm{R}_{\mathrm{s}}$ ) and corresponding BDG in $525 \mu \mathrm{m}$ thick wafers $\left(\mathrm{B}\right.$, high $\left.\mathrm{R}_{\mathrm{s}}\right)$ as a function of the low temperature anneal. BDG results of $400 \mu \mathrm{m}$ thick wafers ( $B$, high $R_{s}, 400 \mu \mathrm{m}$ ) are also shown (open circles, dashed line).
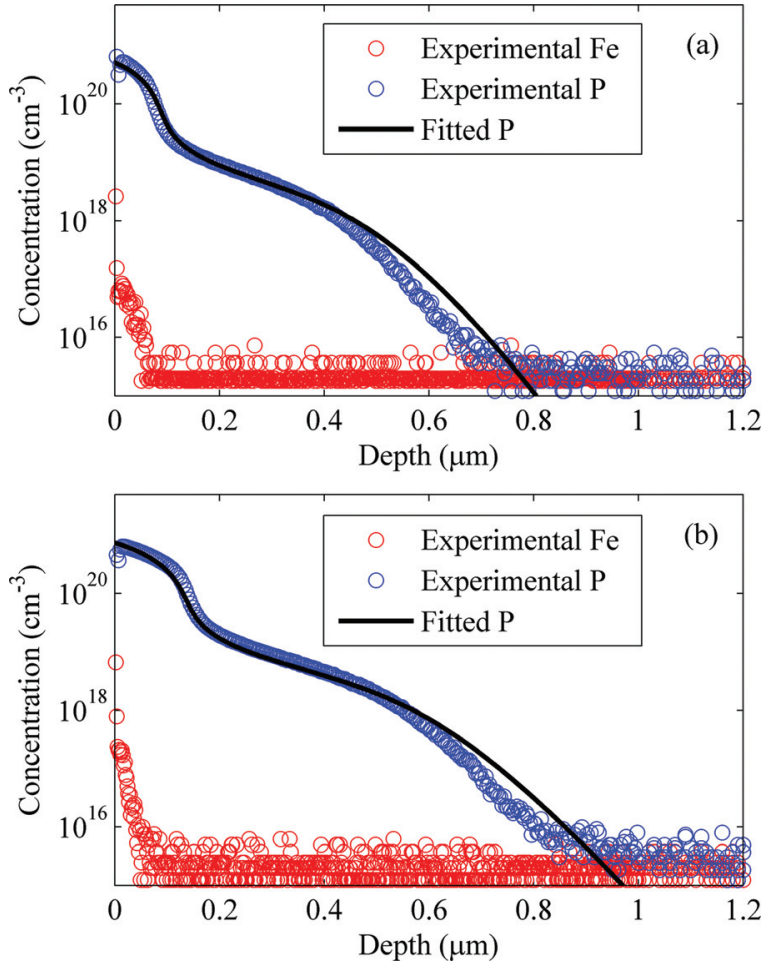

FIG. 3. (Color online) Phosphorus and iron profiles near the wafer surface measured by SIMS after phosphorus in-diffusion (a) $30 \mathrm{~min}$ at $870{ }^{\circ} \mathrm{C}$ and (b) $60 \mathrm{~min}$ at $870^{\circ} \mathrm{C}$, followed by $2 \mathrm{~h}$ anneal at $800^{\circ} \mathrm{C}$. The simulated phosphorus profiles fitted to SIMS data are also shown.

phorus profiles will be used in the simulation chapter for the determination of the segregation coefficient.

\section{B. Simulation results}

As mentioned in the introduction, we have previously proposed a general method to determine the segregation coefficient of iron from the PDG experiments. ${ }^{14}$ We have defined the segregation coefficient of iron, $k_{\text {seg }}$, as the ratio of iron solubility in the phosphorus doped layer to the solubility in the boron doped substrate. As the phosphorus concentration is not constant but decreases toward the wafer bulk, also the segregation coefficient depends on the distance from the wafer surface. By using assumptions of (1) constant supersaturation, i.e., the relation between dissolved iron concentration and solid solubility of iron, and (2) the conservation of mass, we get the following equation ${ }^{14}$

$$
\int_{0}^{x_{d}} k_{\text {seg }}(x) d x=x_{d}+\left(\frac{F e_{\text {init }}}{F e_{\text {bulk }}}-1\right) T_{w}
$$

Here $F e_{\text {init }}$ is the initial iron concentration, $F e_{\text {bulk }}$ is the iron concentration in the bulk after gettering anneal, $T_{w}$ is the wafer thickness, and $x_{d}$ is the depth of the diffused phosphorus layer. With Eq. (1) we can fit the segregation coefficient to experimental data since all the other parameters are known.

We have also presented a possible mechanism for iron segregation into highly phosphorus doped silicon. ${ }^{14}$ We proposed that iron solubility increases in the phosphorus doped layer due to the increase in vacancy concentration, which leads to the formation of negatively charged substitutional 
iron and substitutional iron-phosphorus pairs, $\mathrm{Fe}_{\mathrm{s}} \mathrm{P}$. From the reaction equations we can derive a relation between the reaction equilibrium constants and the segregation coefficient. However, in fitting the data we can use the following simplified approximation

$$
k_{s e g}(x) \approx 1+\frac{K\{n[P(x)]\}^{2}}{n_{i}}
$$

where $n$ is electron concentration, $P$ is phosphorus concentration, $n_{i}$ is the intrinsic carrier concentration, and $K$ is a fitting parameter related to the equilibrium constants. In the analysis presented in this work, $n$ as a function of phosphorus concentration (measured phosphorus profile in Fig. 3), and $n_{i}$ were calculated as presented in Ref. 16.

In our earlier work, we used the experimental data of Nadahara et al. ${ }^{1}$ and Shabani et al. $^{2}$ to obtain an estimate for $k_{\text {seg. }}{ }^{14}$ However, in that study, the number of experimental data points at temperatures below $800^{\circ} \mathrm{C}$ was rather limited. The experimental results presented in Fig. 1 in this paper provide us with the missing low temperature data and thus allow a more reliable determination of $k_{\text {seg. }}$. Figure 4 shows the $K$ values which have been fitted to the experimental results and least squares fit as an Arrhenius plot. For comparison, $K$ data fitted to the previously published experimental results ${ }^{1,2}$ is also presented. The fitting to our low temperature data results in a binding energy of the $\mathrm{Fe}_{\mathrm{S}} \mathrm{P}$ pairs of $1.9 \mathrm{eV}$, which should be more reliable than our previously published value of $1.4 \mathrm{eV}{ }^{14}$

Finally, we study the time dependence of the gettering in order to check that we have used sufficient anneal times at low temperatures to reach the steady state and to verify the validity of the simulations. Figure 5 shows the time dependence of the gettering at $650{ }^{\circ} \mathrm{C}$, i.e., how the bulk iron concentration decreases as the anneal time increases. As seen from the figure, quite long anneal times are indeed necessary to reach the steady state iron concentration. PDG simulations with the revised segregation coefficient match reasonably well to the experiments.

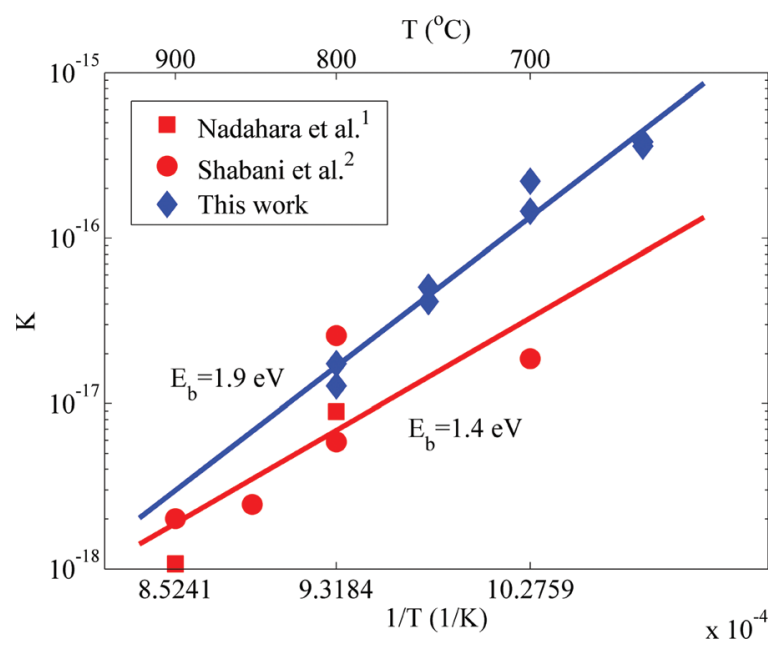

FIG. 4. (Color online) The $K$ values fitted to our experimental data (blue symbols) and earlier literature data ${ }^{1,2}$ (red symbols). Least squares fits to $K$ values determined from our data (blue line) and earlier data (red line) are also shown.

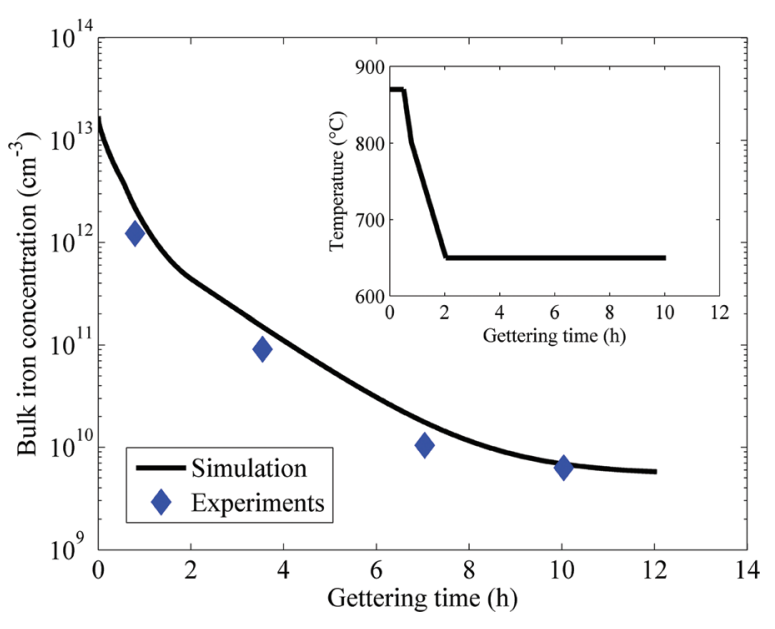

FIG. 5. (Color online) The bulk iron concentrations after phosphorus in-diffusion at $870^{\circ} \mathrm{C}$ for $30 \mathrm{~min}$ followed by a ramp down to $800^{\circ} \mathrm{C}$ (data point at $0.8 \mathrm{~h}$ ) and followed by anneal at $650^{\circ} \mathrm{C}$ for various times. Note that the time to ramp down the temperature is included in the gettering time. The inserted figure shows the temperature profile of the gettering.

\section{DISCUSSION}

In PDG the gettering mechanism seems to be segregation: (1) iron concentration decreases below the solubility limit and (2) ratio is the same at different contamination levels ${ }^{2}$ and (3) the gettering can be quantitatively modeled using the lumped electrical segregation coefficient. Considering the physical mechanism behind the segregation, the equilibrium constant $K$ in our model is in the simplest case the pairing constant of an $\mathrm{Fe}_{\mathrm{S}} \mathrm{P}$ pair. We have proposed that vacancies contribute to the iron solubility. ${ }^{14}$ This is similar to the injection of silicon self-interstitials, which changes the metal population in lattice sites in so called injection gettering. ${ }^{17,18}$ In injection gettering, silicon self-interstitials affect the solubility of metals that are mainly substitutional in silicon. Self-interstitials replace the substitutional metal atoms and thereby move them to interstitial sites. Thus, the concentration of fast diffusing interstitial metal atoms in the bulk increases leading to faster gettering than predicted from substitutional diffusivity. Likewise, we have suggested that a reaction between a doubly negatively charged vacancy and an interstitial iron atom produces negatively charged substitutional iron, which, for one, can react with positively charged phosphorus. ${ }^{14}$ This naturally occurs in the phosphorus doped layer, which means that the time dependence of the gettering (Fig. 5) is well described by interstitial diffusion from the bulk. However, other effects such as a reaction of iron with other phosphorus clusters, which may contain also vacancies, and possible segregation or chemisorption to phosphorus precipitates might also influence the gettering.

When we compare PDG and BDG results, we see that PDG removed iron more effectively than BDG for equal sheet resistance and wafer thickness. These results are in agreement with the earlier results by Istratov et al. which suggested that to produce the same iron segregation gettering effect, a higher boron doping level than phosphorus doping level was needed. ${ }^{12}$ Nevertheless, the gettering efficiency of boron diffusion was surprisingly high compared to the PDG efficiency presented in this work and to the BDG results 
presented in Ref. 4. The high BDG efficiency was explained by the chemisorption of iron by B-Si precipitates. ${ }^{15}$

Simulations of concurrent PDG and BDG without boron precipitates, so called co-gettering, imply that at long gettering times PDG alone is more favorable than co-gettering or BDG alone. ${ }^{19}$ However, at short gettering times the co-gettering was shown to be beneficial as the bulk iron concentration reduces faster due to iron precipitation in the boron layer. Iron precipitation in the boron layer during BDG forms an advantage over PDG also in the case of high initial iron concentration or low phosphorus doping. On the other hand, in a recent study BDG induced only a slight gettering effect even with a low temperature tail, ${ }^{4}$ which apparently is due to the fact that neither boron nor iron was precipitated.

Generally, achieving an effective PDG is fairly easy with a low temperature anneal. In contrast, effective BDG necessitates either boron precipitation or iron precipitation during low temperature anneal. Therefore, BDG conditions must be more accurately optimized. Iron gettering by $\mathrm{B}-\mathrm{Si}$ precipitates requires high boron concentration and a long anneal time, which may also create a practical disadvantage of BDG in comparison to PDG.

\section{CONCLUSIONS}

We have conducted experiments on phosphorus diffusion gettering in monocrystalline silicon with low temperature anneals. The experiments provide steady state iron concentration data at the low temperature range, which has not previously been available. The results show that the phosphorous content has a clear effect on the final gettering efficiency but not much effect on the temperature dependence. From the obtained data, we were able to improve the estimate for the iron segregation coefficient between a phosphorus diffused layer and bulk silicon.

As the assessment of the advantages of n-type silicon solar cells involves PDG and BDG, it was interesting to compare PDG samples to BDG samples with equal sheet resistance. In our experiments, PDG was shown to be more effective than the corresponding BDG but gettering by $\mathrm{B}-\mathrm{Si}$ precipitates can raise the $\mathrm{BDG}$ gettering efficiency to a surprisingly high level. However, it should be kept in mind that achieving effective gettering with BDG requires more accurately controlled gettering conditions, whereas achieving effective PDG is relatively straightforward.

\section{ACKNOWLEDGMENTS}

The authors acknowledge the financial support from the Finnish National Technology Agency, Academy of Finland, Okmetic Oyj, Endeas Oy, Semilab Inc. and VTI Technologies $\mathrm{Oy}$.

${ }^{1}$ S. Nadahara, H. Tsunoda, M. Shiozaki, M. Watanabe, and K. Yamabe, in Defects in Silicon II, Proceedings of the Second Symposium on Defects in Silicon, edited by W. M. Bullis, U. Gösele, and F. Shimura (Electrochemical Society, Pennington, NJ, 1991), pp. 667-674.

${ }^{2}$ M. B. Shabani, T. Yamashita, and E. Morita, Solid State Phenomena 131133, 399 (2008)

${ }^{3}$ A. Laades, K. Lauer, C. Maier, D. Alber, M. Bähr, J. Nutsch, J. Lossen, and A. Lawerenz, Solid State Phenomena 156-158, 381 (2010).

${ }^{4}$ S. P. Phang and D. Macdonald, in Proceedings of the 35th IEEE Photovoltaic Specialists Conference (IEEE, Honolulu, HI, 2010), pp. 000352000356.

${ }^{5}$ P. S. Plekhanov, R. Gafiteanu, U. M. Gösele, and T. Y. Tan, J. Appl. Phys. 86, 2453 (1999).

${ }^{6}$ J. Härkönen, V.-P. Lempinen, T. Juvonen, and J. Kylmäluoma, Sol. Energy Mater. Sol. Cells 73, 125 (2002).

${ }^{7}$ A. Bentzen, E. S. Marstein, R. Kopecek, and A. Holt, in Proceedings of the 19th European Photovoltaic Solar Energy Conference, Paris, France (WIP, Munich, Germany, 2004), pp. 935-938.

${ }^{8}$ P. Manshanden and L. J. Geerligs, Sol. Energy Mater. Sol. Cells 90, 998 (2006).

${ }^{9}$ M. D. Pickett and T. Buonassisi, Appl. Phys. Lett. 92, 122103 (2008).

${ }^{10}$ M. Rinio, A. Yodyunyong, S. Keipert-Colberg, Y. P. Botchak Mouafi, D. Borchert, and A. Montesdeoca-Santana, Prog. Photovolt: Res. Appl. 19, 165 (2011).

${ }^{11}$ A. Haarahiltunen, H. Talvitie, M. Yli-Koski, V. Vähänissi, and H. Savin, in Proceedings of the 24th European Photovoltaic Solar Energy Conference, Hamburg, Germany (WIP, Munich, Germany, 2009), pp. 19611963.

${ }^{12}$ A. A. Istratov, W. Huber, and E. R. Weber, J. Electrochem. Soc. 150, G244 (2003).

${ }^{13}$ M. Seibt, A. Sattler, C. Rudolf, O. Voß, V. Kveder, and W. Schröter, Phys. Status Solidi A 203, 696 (2006).

${ }^{14}$ A. Haarahiltunen, H. Savin, M. Yli-Koski, H. Talvitie, and J. Sinkkonen, J. Appl. Phys. 105, 023510 (2009).

${ }^{15}$ V. Vähänissi, A. Haarahiltunen, H. Talvitie, M. Yli-Koski, J. Lindroos, and H. Savin, Phys. Status Solidi RRL 4, 136 (2010).

${ }^{16}$ A. Bentzen, A. Holt, J. S. Christensen, and B. G. Svensson, J. Appl. Phys. 99, 064502 (2006).

${ }^{17}$ E. Spiecker, M. Seibt, and W. Schröter, Phys. Rev. B 55, 9577 (1997).

${ }^{18}$ S. M. Myers, M. Seibt, and W. Schröter, J. Appl. Phys. 88, 3795 (2000).

${ }^{19}$ J. Schön, M. C. Schubert, W. Warta, H. Savin, and A. Haarahiltunen, Phys. Status Solidi A 207, 2589 (2010). 